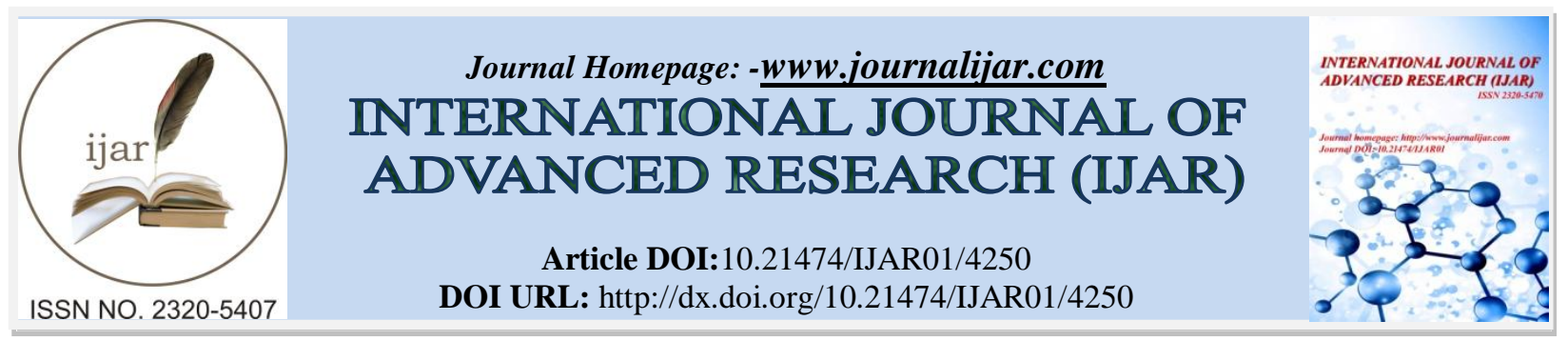

RESEARCH ARTICLE

\title{
EVALUATION OF EARLY GROWTH AND PHOTOSYNTHETIC PIGMENTS OF SOME SPECIES OF ACACIA GROWING IN AL - BAHA REGION IN SAUDI ARABIA.
}

\author{
A. A. Alzandi. \\ Department of Biology, AL-Baha University, Saudi Arabia.
}

\section{Manuscript Info}

Manuscript History

Received: 25 March 2017

Final Accepted: 27 April 2017

Published: May 2017

Key words:-

Acacia species, germination percent, seed elongation, chlorophyll a, chlorophyll b, total chlorophyll.

\section{Abstract}

The scope of this study is to evaluate the germination percentage and early growth as well as photosynthetic pigments contents of five species of Acacia viz (A.asak,A. ,ehrenbergiana, A.etbaica, ,A.hamoulosa, and A. fortilis). Regarding germination percentage, the obtained data showed that A.asakrecorded the highest value (100\%) as compared to relative control (untreated), whileA.fortilisrecorded the lowest value $(66 \%)$. Concerning to the early seedling growth, the highest value $(4.3 \mathrm{~cm})$ was recorded inA.asakwhile the lowest value $(1.4 \mathrm{~cm})$ was measured in A.ehrenbergiana. Concerning photosynthetic pigments, The highest value of chlorophyll a (1.6) $\mathrm{mg} / \mathrm{g}$.fr. wt. was found inA.etbaica while the lowest value (0.98) $\mathrm{mg} / \mathrm{g}$. fr. wt. wasrecordedin A. fortilis . The obtained results clearly showed that the highest value in chlorophyll b (1.1) $\mathrm{mg} / \mathrm{g}$. fr.wt. was recorded in $A$. asakwhile the lowest content $(0.86) \mathrm{mg} / \mathrm{g}$.fr.wt. was detected in A. hamoulosa.Regarding total chlorophyll content.The highest amount of total chlorophyll (2.6) $\mathrm{mg} / \mathrm{g}$.fr.wt.was determined in A.asakwhile the lowest content $(1.98) \mathrm{mg} / \mathrm{g}$.fr.wt. was determined in A.ehrenbergiana.

Copy Right, IJAR, 2017,. All rights reserved.

\section{Introduction:-}

Generally, Acacia genus distributed naturally in Kingdom of Saudi Arabia especially in western and southern regions. This study was carried out in Al-Baha region which constitutes different species of Acacia. Many studies were carried out on the growth of Acacia trees and its importance to the environment (Palmberg, 1981, Aref, 1996). Al- Mefarrej(2012) studied different species of Acacia in Al-Baha region and reported clearly variation between these species. Aref and El-Atta (2013) carried out a study on some Acacia species. Walyet. al, (2012)stated clearly variation in some morphological characters of some species of Acacia seeds. Al-Gohary and Mohamed(2007) carried out a morphological study on seed size, color, texture as well as seed dimensions on some species of Acacia growing in Egypt (A.fortilis , A. oerfota ,A asak, A. ehrenbergiana and A. etbaica). Regarding seed germination, (Arefet al., 2011) reported that seed germination percentages were increased after treatment of some Acacia species (A .asak, A . ehrenbergiana , A. etbaica, A. gerradii and A. origena) with sulfuric acid (98\%) for 15 min.Presence of chlorophyll in green plants makes them unique in living world for they only can capture the solar energy and convert it into chemical energy. It is a phenomenon of utmost significance for the existence of the entire life on this plant (Tiwari and Raj, 2002).Since animals and humans obtain their food supply by eating plants, so photosynthesis can be said to be the source of our life (Devilin,1983). The leaf may be viewed as a photosynthetic machine, superbly engineered to carry out photosynthesis efficiently (Hopkins et al.,2003).Chlorophyll content in leaf tissue varies 
with species, age of plants and growing season. Among the climatic factors light and temperature during the growth period have more pronounced effect on chlorophyll content (Bhatt and Sinha , 1990). The present investigation was conducted to study the variations in photosynthetic pigments as well as early seedling growth of some species of Acacia(A.asak ,A. ,ehrenbergiana ,A.etbaica , ,A.hamoulosa, and A. fortilis) .

\section{Study site:-}

Acacia species distributed naturally in Kingdom of Saudi Arabia, but the density of these species increased in Western and Southern regions . This study was carried out in Al-Baha region(about 12000Km2) which, Geographically, located between longitude $41-42^{\circ} \mathrm{E}$ and latitude $19-20^{\circ} \mathrm{N}$, to study naturally growing Acacia species.

\section{Materials and Methods:- Seeds Collection:-}

Seeds of Acacia species ( A.fortilis , A. ehrenbergiana, A.asak,A,hamoulosa and A.etbaica) were collected during spring season from different localities in AL-Baha region in Kingdom of Saudi Arabia.

\section{Seed germination and early growth:-}

Seeds of equal sizes were sterilized by soaking in $10 \%$ sodium hypochlorite for 10 minutes then soaked in Sulfuric acid (98\%) for 10 minutes. After washing with distilled water, seeds allowed to germinate at $\left(25^{\circ} \mathrm{c}\right)$ in Petri dishes of equal sizes. One piece of filter paper and $5 \mathrm{ml}$ of distilled water were put in each Petri dish. Seeds were then transferred into the filter paper, with 10 seeds per dish and $1 \mathrm{~cm}$ or larger distance between each seed .For untreated experiments (control), distilled water only was used. For the germination rate and root growth investigation, seeds were allowed to germinate for 2 days for all treatments and 10 days for untreated (control), and then seed germination percent $(\%)$ was calculated as well as seedling root length $(\mathrm{cm})$ was measured for treatments and their respective controls. At least, three replicates were carried out for each treatment and related control. A seed was considered to have germinated when radical emerged from the seed coat. The germination percent was calculated as the proportion of the seeds that germinated to total number of seeds multiplied by 100 .

\section{Photosynthetic Pigments:-}

The amount of chlorophyll a, chlorophyll b, and total chlorophyll in terms of $\mathrm{mg} / \mathrm{g}$. fr .wt .were calculated by using the following formula given by Goodwin (1965).Three replicates were carried out for each experiment.

$>$ Chl.a=12.7(A663)-2.69(A645)xV/100XW mg/g fr.wt.

$>$ Chl. $\mathrm{b}=22.9(\mathrm{~A} 645)-4.68(\mathrm{~A} 663) \mathrm{X} / 100 \mathrm{XW} \mathrm{mg} / \mathrm{g}$ fr.wt.

$>$ Total chl. $=22.2(\mathrm{~A} 645)+8.02(\mathrm{~A} 663) \mathrm{XV} / 100 \mathrm{xW} \mathrm{mg} / \mathrm{g}$ fr.wt.

\section{Results and Discussion:-}

\section{Germination and growth performances:-}

Results of the present investigation (Table 1. and Fig.1) clearly revealed markedly variation regarding seed germination percent among Acacia species. The highest percentage of seed germination (95\%) was recorded in case of A. asak, while the lowest one (66\%) was observed in A. fortilis. Regarding seedling growth the obtained data cleared revealed that the highest reading of root elongation $(4.5 \mathrm{~cm})$ was recorded in case of A.fortilis, while the lowest value $(1.8 \mathrm{~cm})$ was observed in A, ehrenbergiana. In this regard, some investigators reported that seed germination and seedling emergence may be affected by internal factors as seed coat dormancy and seed embryo (Agrawal and Dadlani, 1995 ; Olmezet al., 2008), or external factors as light intensity, temperature, water and oxygen (Mehrafarinet al.,2011; Hartmann et al.,2007; Kogeret al.,2004). Many authors demonstrated that some materials as waxes, lipids, cellulose and lignin may prevent seed coats permeability to water (Turner et al. , 2005; Jayasuriyaetal.,2007). Some previous studies stated that the seeds of some plants which having hard seed coats must be treated with different treatments of sulfuric acid or some organic solvents for enhancement their germination development (Ren and Tao , 2004 ; Okunomo and Bosah,2007; kassaetal.,2010). Results of the present work clearly showed that treatments of all tested seeds with sulfuric acid for 10 minutes resulting in enhancement of seed germination and seedling growth as compared to untreated experiments (control). Our results consistent with those reported out by Arefet al. (2011), Aref and EL-Atta (2013) Okunomo and Bosah (2007) and Kassaetal.(2010).In this concern ,Legesse (2010) stated that treatment of seeds with sulfuric acid or boiling water overcoming the hardness of seed coat resulting in easily water permeability of seed coats to water. 
Table 1:-Seed germination percent (\%) of different Acacia species for treatments and related controls.

\begin{tabular}{|c|c|c|}
\hline seicepS & lortnoc & tnemtaerT \\
\hline A.asak & $\mathbf{9 0}$ & $\mathbf{1 0 0}$ \\
\hline A.ehrenbergiana & $\mathbf{4 3}$ & $\mathbf{6 9}$ \\
\hline A.hamoulosa & $\mathbf{7 2}$ & $\mathbf{8 7}$ \\
\hline A.fortilis & 20 & 66 \\
\hline A.etbaica & 68 & $\mathbf{8 0}$ \\
\hline
\end{tabular}

Table 2:-Elongation of root $(\mathrm{cm})$ of the different species of Acacia for treatments and related controls.

\begin{tabular}{|c|c|c|}
\hline seicepS & control & Treatment \\
\hline A.asak & $\mathbf{2 . 9} \pm \mathbf{0 . 1 9}$ & $\mathbf{4 . 3} \pm 0.32$ \\
\hline A.ehrenbergiana & $\mathbf{0 . 7} \pm \mathbf{0 . 1 7}$ & $\mathbf{1 . 4 \pm 0 . 1 1}$ \\
\hline A.hamoulosa & $\mathbf{2 . 3 \pm 0 . 2 8}$ & $\mathbf{3 . 6} \pm 0.32$ \\
\hline A.fortilis & $\mathbf{0 . 8} \pm \mathbf{0 . 1 8}$ & $\mathbf{1 . 7} \pm 0.22$ \\
\hline A.etbaica & $\mathbf{1 . 3} \pm \mathbf{0 . 5 4}$ & $\mathbf{2 . 8} \pm \mathbf{0 . 1 9}$ \\
\hline
\end{tabular}

( standard deviation \pm Mean value)

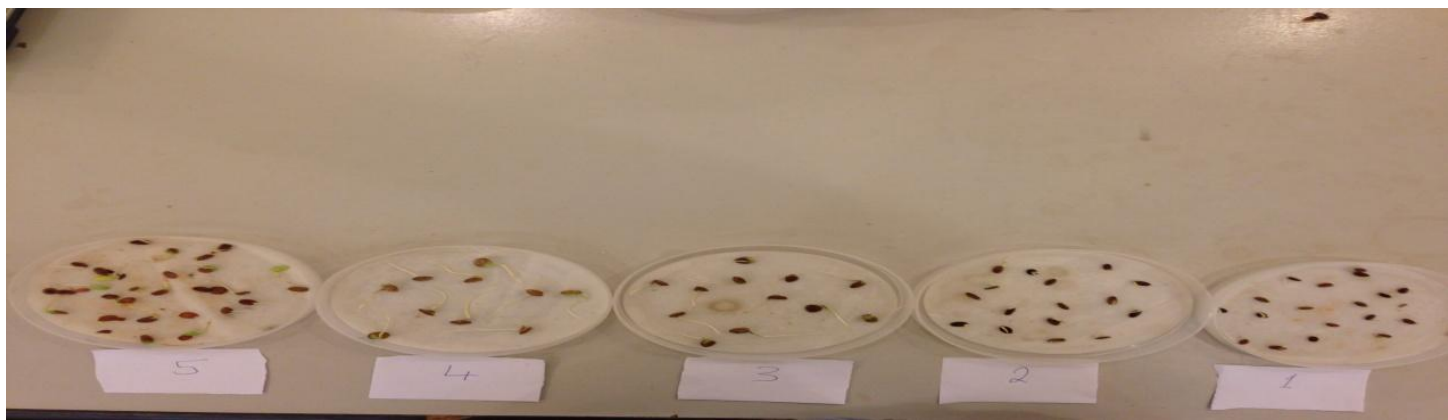

Fig 1:-Acacia ampliceps seedlings for different species:

1. A.asak.

2. A.ehrenbergiana.

3. A.hamoulosa.

4. A.fortilis.

5. A.etbaica.

\section{Photosynthetic pigments:-}

The results of the present investigation (Table 3) clearly showed that the average chlorophyll a was observed the maximum (1.6) mg/g.fr.wt. inA.etbaica while the minimum average content (0.98) was detected in A. fortilis. As regard to chlorophyll $b$ content, the obtained data revealed that the maximum average value(1.1) $\mathrm{mg} / \mathrm{g}$.fr.wt. was recorded in A.asak while the minimum $(0.86) \mathrm{mg} / \mathrm{g}$. fr.wt. was observed in A.hamoulosa. The maximum average value of total chlorophyll (2.6) mg/g.fr.wt.was observed in A.asak while the minimum content (1.98) mg/g.fr.wt. was recorded in A.ehrenbergiana. The present study indicates that there was wide variation in photosynthetic pigments among the studied species. By comparing the values of total chlorophyll among the investigated five species of Acacia, the higher content was observed in A.asak. The obtained data of this work consistent with reported out by CHARU GUPTA and VANDANA MISHRA(2010) .Studies on estimation of photosynthetic pigments indicate clearly variation in their contents and exhibit seasonal alteration among three species of Mesembryaanthemum(Tantawy et al.,2004). So it was conducted from present investigation that the higher value of total chlorophyll of A.asak exhibits a potential productivity than the other species. Additionally, the higher contents of photosynthetic pigments can be used as precursors of some vitamins and play an important function of protecting the photosynthetic apparatus from destruction by light (Lea and Leegood, 1999). 
Table 3:-Photosynthetic pigment contents (mg/g.fr.wt.) of five species of Acacia.

\begin{tabular}{|c|c|c|c|}
\hline Species names & Chlorophyll a & Chlorophyll b & Total chlorophyll \\
\hline A.asak & $1.2 \pm 0.87$ & $1.1 \pm 0.92$ & $2.6 \pm 0.66$ \\
\hline A.ehrenbergiana & $1.4 \pm 0.78$ & $\mathbf{0 . 9 3} \pm 0.74$ & $1.98 \pm 0.95$ \\
\hline A.hamoulosa & $1.3 \pm 0.49$ & $\mathbf{0 . 8 6} \pm 0.77$ & $2.3 \pm 0.57$ \\
\hline A.fortilis & $\mathbf{0 . 9 8} \pm 0.96$ & $1.0 \pm 0.46$ & $2.2 \pm 0.49$ \\
\hline A.etbaica & $1.6 \pm 0.59$ & $\mathbf{0 . 9 7} \pm 0.12$ & $2.4 \pm 0.87$ \\
\hline
\end{tabular}

( standard deviation \pm Mean value )

\section{References:-}

1. Agrawal, P.K., and Dadlani M. (1995). Techniques in seed science and technology. $2^{\text {nd }}$ Ed. India, South Asian Publishers Limited: 179.

2. Al-Gohary, I. H. \&Mohamed, Amaal H. (2007).Seed Morphology of Acacia in Egypt and its Taxonomic Significance. International Journal of Agriculture \&Biology .3:435-438.

3. Al-Mefarrej, H.A. (2012). Diversity and frequency of Acacia spp. in three regions in the Kingdom of Saudi Arabia. African Journal of Biotechnology .11(52):11420-11430.

4. Aref, I.M. (1996). The distributiol and ecobhsiology of Acaciasbecias in south wastarn zone of Saudi Arabia,Ph.D Thesis University of Edinburgh.

5. Aref, I.M., El Atta, H.A., Al Shahrani, T., and Ahamed A.I. (2011). Effects of seed pretreatment and seed source on germination of five Acacia spp., Afr. J. Bio. technol. 10(71): 15901-15910.

6. Aref, I.M. and El Atta,H.A. (2013). Growth performance and stand structure of some Acacia spp in south western Saudi Arabia. International Journal of Plant, Anemal and Environmental Sciences. 3: 35-41.

7. Bhatt, R.K. and Sinha, N.C. (1990). Photosynthetic pigments- a prerequisite of grass productivity, Photosynthetia, 24 (1): 147-150.

8. Bogorad, L. (1967). The organisation and Development of Chloroplasts. In: J.M. Alien (ed.) Molecular organisation and biological functions. New York. Harper and Row.

9. CHARU GUPTA and VANDANA MISHRA(2010).Effect of seasonal variation in photosynthetic pigments of few medicinal plant species of Jhansi.International Journal of plant sciences.Vol.5 Issue 2:676-678.

10. Devilin, Robert, M. and Witham, Francis, H. (1983). Plant physiology CBS Pub. And Distributors, 485, Jain bhawan, BholaNath Nagar, Shahdara, Delhi. Pp 577.

11. Goodwin, T.W. (1965). Chemistry and biochemistry of plant pigments. Academic pre ss . New York.

12. Hartmann H.T. Kester, D. E., Davies, F.T., and Genve, R.I. (2007). Hartmann and Kester's plant propagation, principles and practices. seventh edition. Prentice-Hall of India Private limited. pp: 880.

13. Hopkins William, G. and Huner Norman, P.A. (2003).Introduction to plant physiology, The university of Western Ontario, London. pp.63.

14. Jayasuriya, K.M.G.G., Baskin, J.M., Geneve, R.L., and Baskin, C.C. ( 2007). Morphology and anatomy of physical dormancy in Ipomoealacunosa: identification of the water gap in seeds of Convolvulaceae (Solanales). Ann. Bot. 100: 13-22.

15. Kassa, A., Alia, .R, Tadesse W., Pando, V., and Bravo, F.,(2010). Seed germination and viability in two African Acacia species growing under different water stress levels. Afr. J. Plant Sci., 4(9): 353-359.

16. Koger, C.H., Reddy, K.N, and Poston, D.H. (2004). Factors affecting seed germination, seedling emergence, and survival of texasweed (Caperoniapalustris). Weed Sci. 52: 989-995.

17. Lee,P.J. and Leegood,R.C.(1999):Plant Biochemistry and Molecular Biology.John Wiley\&Sons.Ltd.England,355 pp.

18. Legesse N. (2010). A selection of Ethiopia's Indigenous Trees: Biology, Uses and Propagation Techniques. Addis Ababa University Press, Addis Ababa. pp386.

19. Mehrafarin, A., Badii, H.N., GhorbanNoormohammadi ,G., Zand, E., ShamsaliRezazadeh, S., and ArdeshirQaderi, A. ( 2011). Effects of environmental factors and methanol on germination and emergence of Persian Fenugreek (Trigonellafoenum-graecumL.), Afri. J. Agric. Res. 6(19): 4631-4641.

20. Okunomo, K., and Bosah, B.O. ( 2007). Germination response of Acacia senegal (Linn.) seeds to various presowingtrteatments in the nursery. Agric. J. 2(6): 681-684.

21. Olmez, Z., Gokturk A., Karasah B., Yilmaz H. (2008). Effects of cold stratification and $\mathrm{H}_{2} \mathrm{SO}_{4}$ pretreatments on germination of three provenances of smoke-tree (CotinuscoggygriaScop.) seeds in greenhouse and laboratory conditions. Afr. J. Biotechno. 8(19): 4964-4968.

22. Palmberg, C. (1981). A vital fuel wood gene pool is in danger, Unasylra. 133: 22-30. 
23. Ren, J., and Tao, L. (2004). Effects of different pre-sowing seed treatments on germination of 10 Calligonumspecies. For. Ecol. Manage. 195: 291- 300.

24. Shiyk, A.A., Kater,V.L., Vlasenok,L.I. and Gaponenko, V.I. (1963).The final stages of biosynthesis of chlorophyll a and b in the green leaf. Phochem. Photobiol., 2 : 129.

25. Tantawy,H.,Shayeb,F.and EL-Kholy(2004).Eco-physiological and phytochemical evaluation of three Mesemberyanthemumspecies.Egypt.J. Biotechnol.Vol.17,173-191.

26. Tiwari, S.L. and Rai, Shashi (2002). Effect of seasonal variation in photosynthetic pigments of Bhopal. Biodiversity strategies for conservation. A.P.H Publishing Corporation New Delhi. pp. 331-337.

27. Turner, S.R., Merritt, D.J., Baskin, C.C., Dixon, K.W., and Baskin, J.M., (2005). Physical dormancy in seeds of six genera of Australian Rhamnaceae. Seed Sci. Res. 15:51-58.

28. Waly, N.M., Al-Zahrani, H.S., and Felemban, W.F. (2012). Taxonomical studies of someAcacia seeds growing in Saudi Arabi. . Journal of American science. 8(3):264-275. 